Check for updates

Cite this: RSC Adv., 2019, 9, 39064

Received 30th October 2019

Accepted 11th November 2019

DOI: 10.1039/c9ra08936e

rsc.li/rsc-advances

\section{Chemical looping hydrogen production with modified iron ore as oxygen carriers using biomass pyrolysis gas as fuel}

\author{
Tingting $\mathrm{Xu},{ }^{\mathrm{a}}$ Bo Xiao, ${ }^{\mathrm{a}}$ Gensheng $\mathrm{Fu}{ }^{\mathrm{a}}$ Sicheng Yang ${ }^{\mathrm{b}}$ and Xun Wang (D) *a
}

The chemical looping hydrogen (CLH) production was conducted in a fluidized bed reactor with the modified iron ore oxygen carriers (OCs) using simulated biomass pyrolysis gas (BPG) as fuel. Both carbon capture efficiency and hydrogen yield increased with the elevated reaction temperature in the fuel reactor (FR). As the reduction time in the FR increased, the carbon capture efficiency decreased but the hydrogen yield increased. An FR temperature of $900{ }^{\circ} \mathrm{C}$ and reduction time of $40 \mathrm{~min}$ in the FR were optimal conditions for $\mathrm{CLH}$ production. At this condition, the carbon capture efficiency for the $\mathrm{NiO}$-iron ore, $\mathrm{CuO}$-iron ore $\mathrm{CeO}$-iron ore and iron ore were $83.29 \%, 82.75 \%, 70.05 \%$ and $40.46 \%$, respectively. The corresponding hydrogen yield and hydrogen purity were $8.89 \mathrm{mmol} \mathrm{g}^{-1}$ and $99.02 \%, 7.78 \mathrm{mmol} \mathrm{g}^{-1}$ and $99.68 \%, 6.25 \mathrm{mmol} \mathrm{g}^{-1}$ and $99.52 \%$, and $2.45 \mathrm{mmol} \mathrm{g}^{-1}$ and $97.46 \%$, respectively. The presence of $\mathrm{NiFe}_{2} \mathrm{O}_{4}, \mathrm{CuFe}_{2} \mathrm{O}_{4}$ and $\mathrm{CeFeO}_{3}$ in the modified iron ore samples enhanced the reactivity of the iron ore and promoted its reduction. Both $\mathrm{NiO}$-iron ore and $\mathrm{CeO}_{2}$-iron ore exhibited good cycle performance, while the sintering of the $\mathrm{CuO}$-iron ore resulted in a decrease in the reactivity. Compared with the $\mathrm{CuO}$-iron ore and $\mathrm{CeO}$-iron ore, the $\mathrm{NiO}$-iron ore was more appropriate for hydrogen production due to its high hydrogen yield and good cycle performance.

\section{Introduction}

Hydrogen, an excellent energy carrier with high energy density and environmentally friendly properties, is considered a promising alternative energy source toward resolving the depletion of fossil fuels and environmental issues, such as the pollutant and greenhouse gas emissions. ${ }^{1}$ More than $80 \%$ hydrogen around the world is produced by the steam reforming technology using fossil fuel as feedstock. ${ }^{2}$ However, this technology has disadvantages, such as high energy consumption, a low energy integration efficiency, and serious $\mathrm{CO}_{2}$ emissions. ${ }^{2}$ Chemical looping hydrogen $(\mathrm{CLH})$ production has received a great deal of attention in recent years because it can produce high purity hydrogen, and also capture carbon dioxide. ${ }^{3,4}$ Furthermore, the negative $\mathrm{CO}_{2}$ emissions can be achieved in CLH production using the carbon neutral biomass derived fuels, such as bio-oil, syngas and biochar. ${ }^{5}$

It is very crucial to select a suitable oxygen carrier (OC) in the $\mathrm{CLH}$ production process. Metal oxides, such as the oxides of Ce, $\mathrm{Fe}, \mathrm{Cu}, \mathrm{Ni}$, Co and $\mathrm{Mn}$, have been proposed as possible OCs for the hydrogen production. ${ }^{6-10}$ Among various metal oxides, $\mathrm{Fe}_{2} \mathrm{O}_{3}$ was considered an ideal candidate for $\mathrm{CLH}$ production

${ }^{a}$ School of Environmental Science \& Engineering, Huazhong University of Science \& Technology, Wuhan 430074, China. E-mail: xunw@hust.edu.cn; Tel: +86 15271949823

${ }^{b}$ China Urban Construction Design \& Research Institute Co., Ltd. (CUCD), China due to its favorable thermodynamics, low cost, nontoxicity and environmentally friendly properties in Nature. ${ }^{11}$ However, $\mathrm{Fe}_{2} \mathrm{O}_{3}$ cannot be regenerated completely just using steam as the oxidizing medium due to the limitation of the thermodynamic property. An air reactor is needed to oxide the reduced oxygen carrier. Therefore, as shown in Fig. 1, a three-reactor CLH production system was developed. ${ }^{\mathbf{4 , 1 2}}$ The three-reactor CLH production system consists of a fuel reactor (FR), a steam reactor (SR) and an air reactor (AR). $\mathrm{Fe}_{2} \mathrm{O}_{3}$ is reduced to $\mathrm{Fe}$ and $\mathrm{FeO}$ by fuel in the FR first, and then $\mathrm{Fe}$ and $\mathrm{FeO}$ are oxidized to $\mathrm{Fe}_{3} \mathrm{O}_{4}$ by steam to obtain hydrogen in the SR where the water splitting occurs. High purity hydrogen is produced. Afterwards, $\mathrm{Fe}_{3} \mathrm{O}_{4}$ is transferred back to the AR where it is oxidized to $\mathrm{Fe}_{2} \mathrm{O}_{3}$ by air.

In fact, a rapid decrease in the reactivity of pure iron oxide was observed during the redox cycles, due to agglomeration and sintering of $\mathrm{Fe}$ and $\mathrm{Fe}_{3} \mathrm{O}_{4}$ during the chemical looping processes. A large number of studies have been done to enhance the reactivity, stability and cycle performance of the Fe-based OCs by adding some metal oxides. Ordinarily, these OCs involve the formation of new compounds, which may have a higher reactivity and enhanced reduction rate. ${ }^{13}$ Huang et al. ${ }^{\mathbf{1 4}}$ illustrated that iron ore modified by $\mathrm{NiO}$ was appropriate in the CLR with biomass char owing to the fact that the formation of the spinel-type nickel iron oxide $\mathrm{NiFe}_{2} \mathrm{O}_{4}$ improved the reaction rate of char gasification. Chen et al. ${ }^{15}$ reported that the $\mathrm{NiO}$ addition improved the maximum reaction rate of the iron-based 


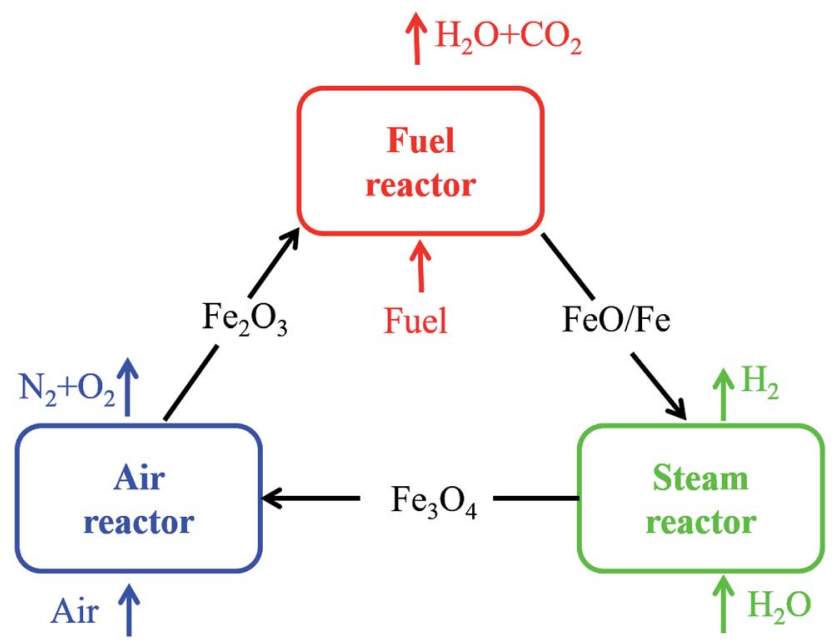

Fig. 1 Schematic of the three-reactor CLH production system.

OCs in the oxidation stage and promoted the further reduction of Fe-oxides to Fe. Ismail et al. ${ }^{16}$ demonstrated that the CaOmodified $\mathrm{Fe}_{2} \mathrm{O}_{3}$ OCs exhibited higher reactivity and higher stability compared to the unmodified $\mathrm{Fe}_{2} \mathrm{O}_{3}$. Siriwardane et al. ${ }^{17}$ found that the presence of $\mathrm{Cu}$ promoted the deeper reduction of $\mathrm{Fe}_{2} \mathrm{O}_{3}$, and improved the oxidation and reduction rates. Sun et al. ${ }^{18}$ confirmed that $\mathrm{CeO}_{2}$ could effectively inhibit carbon deposition or $\mathrm{Fe}_{3} \mathrm{C}$ formation in CLH production with ironbased oxygen carriers.

Natural iron ore, as one of the iron-based OCs, have been intensively studied in chemical looping processes due to their lower application cost. ${ }^{19-22}$ In recent years, natural iron ores have been gradually applied to the CLH production process. Zeng et al. ${ }^{23}$ investigated the bio-oil CLH production process using an Austrian MAC iron ore as the OC. The hydrogen purity and hydrogen yield at $96 \%$ and $635 \mathrm{~mL}$ per $\mathrm{mL}$ oil, respectively, were achieved with a steam-to-oil ratio of 1.5. Xiao et al. ${ }^{24}$ found that the carbon and $\mathrm{Fe}_{3} \mathrm{C}$ formation led to a decrease in the reducibility of the four iron-based natural minerals. In general, the low redox reactivity is the main issue with using natural iron ore as OCs..$^{25-28}$

Similarly, few studies have been reported in which the metals, $\mathrm{Na}, \mathrm{K}, \mathrm{Cu}$ and $\mathrm{Ca}$ etc., were implemented to enhance the reactivity of natural iron ores. Wang et al. ${ }^{29}$ reported that adding $\mathrm{K}$ and $\mathrm{Cu}$ had significant effects on enhancing the reduction reactivity of hematite, as well as elevating the hydrogen production in the CLH production process. Liu et al. ${ }^{30}$ reported that the presence of $\mathrm{K}$ decreased the carbon deposition, and increased the reduction rate of iron ore and hydrogen yield in CLH production. Gu et al. ${ }^{31}$ confirmed the feasibility of CLH production using the mixture of iron ore and biomass ash as OCs. Although some encouraging results were presented in the abovementioned studies, the issues of modified iron ores (such as sintering, agglomeration and volatilization of modified components) still exist. ${ }^{26,30,32,33}$ It is necessary to explore the modified iron ore OC with high reactivity and long-term stability for high purity hydrogen production.
In this study, the feasibility of CLH production with biomass pyrolysis gas using modified iron ore as OCs was evaluated. Modified iron ores $\left(\mathrm{M}_{x} \mathrm{O}_{y}\right.$-iron ore, $\mathrm{M}=\mathrm{Ni}, \mathrm{Cu}$ and $\left.\mathrm{Ce}\right)$ were prepared by the sample impregnation method. The CLH production experiments were conducted in a laboratory-scale fluidized bed reactor. The carbon capture efficiency, hydrogen yield, hydrogen purity and the reactivity of the OCs in CLH production process were investigated. The fresh and used OCs were characterized to evaluate their performance.

\section{Experimental}

\subsection{Raw materials}

The powder sample of the raw iron ore was obtained from the Wuhan Iron and Steel (Group) Company, which was supplied by the Chengchao iron ore miner, Ezhou, Hubei, China. The raw iron ore powder was first calcined at $900{ }^{\circ} \mathrm{C}$ for $6 \mathrm{~h}$ under atmospheric air. Then, the iron ore was grinded and sieved to 60-250 $\mu \mathrm{m}$ for use. The chemical components of the calcined iron ore were determined by X-ray fluorescence (XRF) spectroscopy. The results are given in Table 1.

In this study, a simulated biomass pyrolysis gas (BPG) was used to reduce the OCs in the fluidized-bed reactor. The BPG $\left(10 \% \mathrm{H}_{2}+10 \% \mathrm{CO}+5 \% \mathrm{CH}_{4}+75 \% \mathrm{~N}_{2}\right.$ balance) was purchased from the XiangYun Industry Co., Ltd. (Wuhan, China). All chemicals used in this research study were of analytical grade, and purchased from the Sinopharm Chemical Reagent Co., Ltd. (Shanghai, China).

\subsection{Preparation of OCs}

The modified iron ore OCs, $\mathrm{M}_{x} \mathrm{O}_{y}$-iron ore $\left(\mathrm{M}_{x} \mathrm{O}_{y}=\mathrm{NiO}, \mathrm{CuO}\right.$ and $\mathrm{CeO}_{2}$ ) were prepared via the incipient wetness impregnation method. The mass fraction of $\mathrm{NiO}, \mathrm{CuO}$ and $\mathrm{CeO}_{2}$ were fixed at $10 \mathrm{wt} \%$ for all OCs. First, $\mathrm{Ni}\left(\mathrm{NO}_{3}\right)_{2} \cdot 6 \mathrm{H}_{2} \mathrm{O}, \mathrm{Cu}\left(\mathrm{NO}_{3}\right)_{2}-$ $\cdot 3 \mathrm{H}_{2} \mathrm{O}$ and $\mathrm{Ce}\left(\mathrm{NO}_{3}\right)_{4} \cdot 6 \mathrm{H}_{2} \mathrm{O}$ were accurately weighed and dissolved in deionized water to obtain nitrate aqueous solutions. Then, the aqueous solutions of $\mathrm{Ni}\left(\mathrm{NO}_{3}\right)_{2} \cdot 6 \mathrm{H}_{2} \mathrm{O}, \mathrm{Cu}\left(\mathrm{NO}_{3}\right)_{2} \cdot 3 \mathrm{H}_{2} \mathrm{O}$ and $\mathrm{Ce}\left(\mathrm{NO}_{3}\right)_{4} \cdot 6 \mathrm{H}_{2} \mathrm{O}$ were each transferred to the beaker containing iron ore powder. The resulting mixtures were stirred slowly at $80^{\circ} \mathrm{C}$ for $12 \mathrm{~h}$, dried at $105^{\circ} \mathrm{C}$ for $48 \mathrm{~h}$ in a drying oven, and calcined at $1000^{\circ} \mathrm{C}$ for $6 \mathrm{~h}$ in a muffle furnace. Finally, the resulting sample was cooled to room temperature, crushed, and sieved into particles with a size range of $50 \mu \mathrm{m}$ to $430 \mu \mathrm{m}$ for use.

\subsection{Chemical looping hydrogen tests}

The CLH production experiments were carried out in a fluidized-bed reaction system under atmospheric pressure, as shown in Fig. 2. This system consisted of a carrier gas unit,

Table 1 The elemental content of the calcined iron ore

\begin{tabular}{llllll}
\hline Oxide & $\mathrm{Al}$ & $\mathrm{Si}$ & $\mathrm{Ca}$ & $\mathrm{Mg}$ & $\mathrm{Fe}$ \\
wt $\%$ & 2.68 & 3.19 & 2.17 & 2.81 & 88.15
\end{tabular}




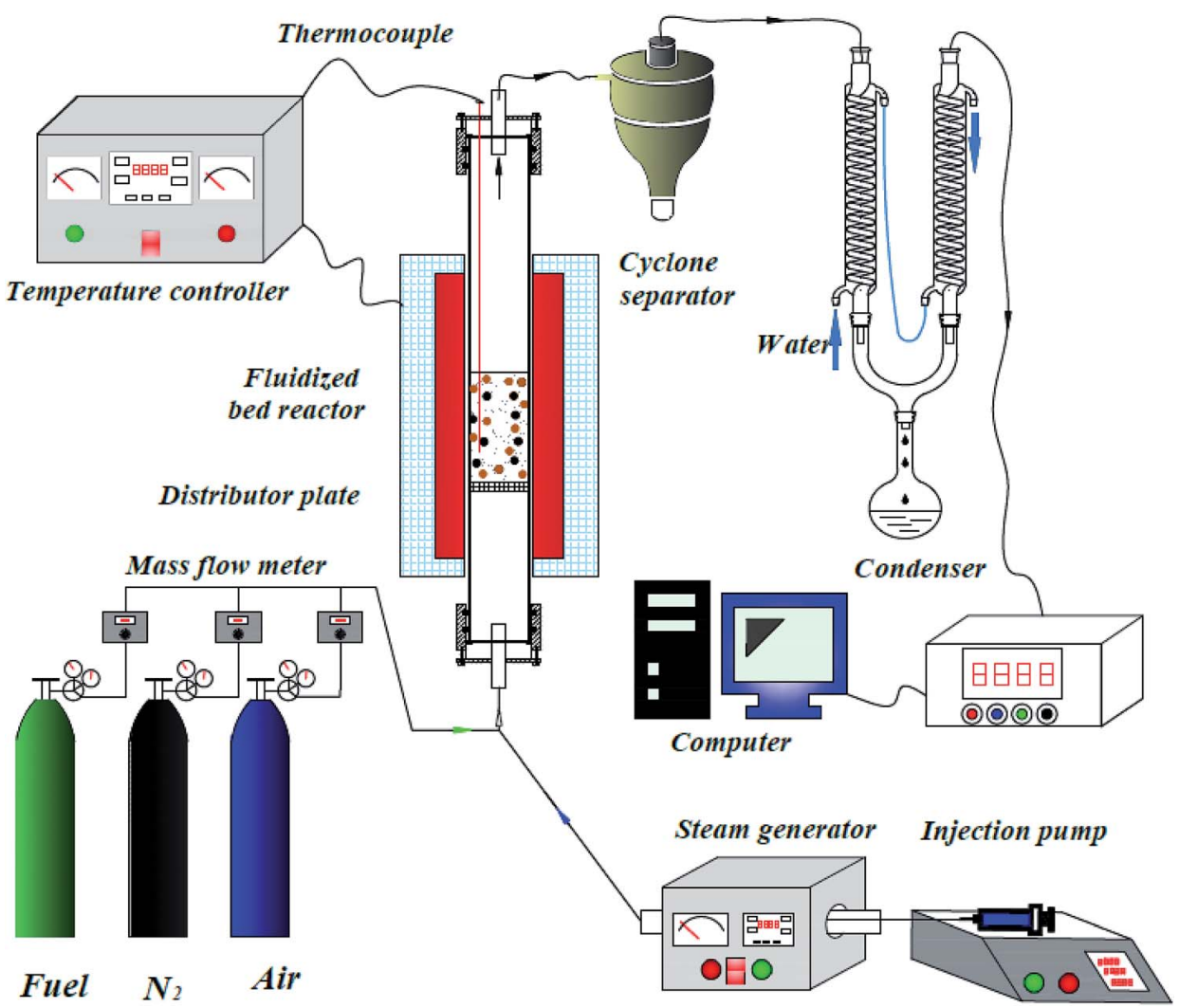

Fig. 2 Reactor system for chemical looping hydrogen production.

fluidized bed reactor, cyclone separator, condenser, and on-line gas analyzer, steam generator and an injection pump.

A quartz tube (i.d. $=30 \mathrm{~mm}$, length $=1000 \mathrm{~mm}$ ) was used as the fluidized bed reactor, with a porous distributor plate placed in the reactor at a distance of $400 \mathrm{~mm}$ from the bottom. The temperature of the fluidized bed reactor was measured by a Ktype thermocouple. The water was injected into the steam generator by an injection pump to obtain steam. The steam was introduced into the fluidized-bed reactor via a tube, which was wrapped by a heated bend. The temperatures of the steam generator and the heated bend were fixed at $300{ }^{\circ} \mathrm{C}$ and $180{ }^{\circ} \mathrm{C}$, respectively.

The CLH production tests can be divided into three stages, namely the reduced stage, steam-oxidized stage and regenerated stage. Prior to each test, $20.0 \mathrm{~g}$ OCs were loaded onto the porous distributor plate in the fluidized-bed reactor. Next, the fluidized-bed reactor was heated to the desired temperature in air $\left(500 \mathrm{~mL} \mathrm{~min}^{-1}\right)$. When the temperature was stable, air was then switched to nitrogen $\left(500 \mathrm{~mL} \min ^{-1}\right)$ to sweep the fluidized-bed reactor for $10 \mathrm{~min}$. In the reduced stage, BPG (500 $\mathrm{mL} \min ^{-1}$ ) was introduced in the fluidized-bed reactor to reduce the OC particles. The reduction time was an important control variable, which changed from $20 \mathrm{~min}$ to $60 \mathrm{~min}$ with an interval of $10 \mathrm{~min}$. Once the reaction ran out of time, BPG was switched to nitrogen $\left(500 \mathrm{~mL} \mathrm{~min}^{-1}\right)$ to purge the reactor for $10 \mathrm{~min}$. In the steam-oxidized stage, nitrogen (500 $\mathrm{mL} \mathrm{min}^{-1}$ ) was used as a carrier gas, and the steam was introduced to the reactor to obtain high purity hydrogen for $60 \mathrm{~min}$. The steam

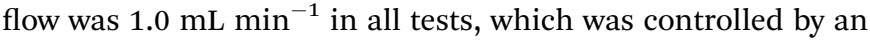
injection pump. In the regenerated stage, air $\left(500 \mathrm{~mL} \mathrm{~min}^{-1}\right)$ was used to regenerate the OCs for $60 \mathrm{~min}$.

The flue gases passed through a cyclone separator, condenser, and on-line gas analyzer (Gasboard-3100, Wuhan Cubic Optoelectronics Co., Ltd.) in order. The gas concentrations (including $\mathrm{CO}, \mathrm{CO}_{2}, \mathrm{CH}_{4}, \mathrm{H}_{2}$ and $\mathrm{O}_{2}$ ) were analyzed and recorded continuously, with the fine particles being collected and the condensable components of the flue gases being removed.

\subsection{Data analysis}

In the reduced stage, $500 \mathrm{~mL} \mathrm{~min}^{-1}$ of BPG was used in the FR. The molar flow of $\mathrm{N}_{2}\left(F_{\mathrm{N}_{2}-\mathrm{FR}}, \mathrm{mol} \mathrm{s}^{-1}\right)$ is a constant in the outlet.

The outlet gas molar flow $\left(F_{\text {out-FR }}, \mathrm{mol} \mathrm{s}^{-1}\right)$ is calculated as

$$
F_{\text {out-FR }}=\frac{F_{\mathrm{N}_{2}-\mathrm{FR}}}{1-\sum x_{\mathrm{i}}}
$$

where $x_{\mathrm{i}}$ denotes the molar fraction of the gas components $(i=$ $\mathrm{CO}_{2}, \mathrm{CO}, \mathrm{CH}_{4}$ and $\mathrm{H}_{2}$ ).

The carbon capture efficiency $\left(\delta_{\mathrm{c}}, \%\right)$ is used to evaluate the conversion degree of carbonaceous gases into $\mathrm{CO}_{2}$ in the fuel reactor. It was calculated as

$$
\delta_{\mathrm{C}}=\frac{\int_{t_{0}}^{t_{1}} F_{\text {out-FR }} x_{\mathrm{CO}_{2}} \mathrm{~d} t}{\int_{t_{0}}^{t_{1}} F_{\text {out-FR }}\left(x_{\mathrm{CO}}+x_{\mathrm{CO}_{2}}+x_{\mathrm{CH}_{4}}\right) \mathrm{d} t} \times 100 \%
$$


where $t_{0}$ and $t_{1}$ denote the start and end reaction times in the FR, respectively.

Similarly, the outlet $\mathrm{N}_{2}$ flow $\left(F_{\mathrm{N}_{2}-\mathrm{SR}}, 500 \mathrm{~mL} \mathrm{~min}^{-1}\right)$ is used as a carrier gas in the steam-oxidized stage. The outlet gas flow $\left(F_{\text {out-SR }} \mathrm{mol} \mathrm{s}^{-1}\right)$ is calculated as

$$
F_{\text {out-SR }}=\frac{F_{\mathrm{N}_{2}-\mathrm{SR}}}{1-\sum y_{\mathrm{i}}}
$$

where $y_{\mathrm{i}}$ denotes the molar fraction of the gas components in the SR ( $\mathrm{i}=\mathrm{CO}_{2}, \mathrm{CO}, \mathrm{CH}_{4}$ and $\mathrm{H}_{2}$ ).

The total volume of hydrogen $V_{\mathrm{H}}(\mathrm{L})$ in the gas products is calculated as:

$$
V_{\mathrm{H}}=22.4 \int_{t_{2}}^{t_{3}} F_{\text {out-SR }} y_{\mathrm{H}_{2}} \mathrm{~d} t
$$

where $t_{2}$ denotes the reaction time in the steam reactor.

The hydrogen yield, $H_{\mathrm{y}}\left(\mathrm{mmol} \mathrm{g}^{-1}\right)$, is calculated as

$$
H_{\mathrm{y}}=\frac{1000 V_{\mathrm{H}}}{22.4 m_{\mathrm{OC}}}
$$

where $m_{\mathrm{OC}}(\mathrm{g})$ is the mass of the OC in each test.

The hydrogen purity $\left(H_{\mathrm{p}}\right)$ is calculated as

$$
H_{\mathrm{p}}=\frac{y_{\mathrm{H}_{2}}}{\sum_{\mathrm{i}} y_{\mathrm{i}}} \times 100 \%
$$
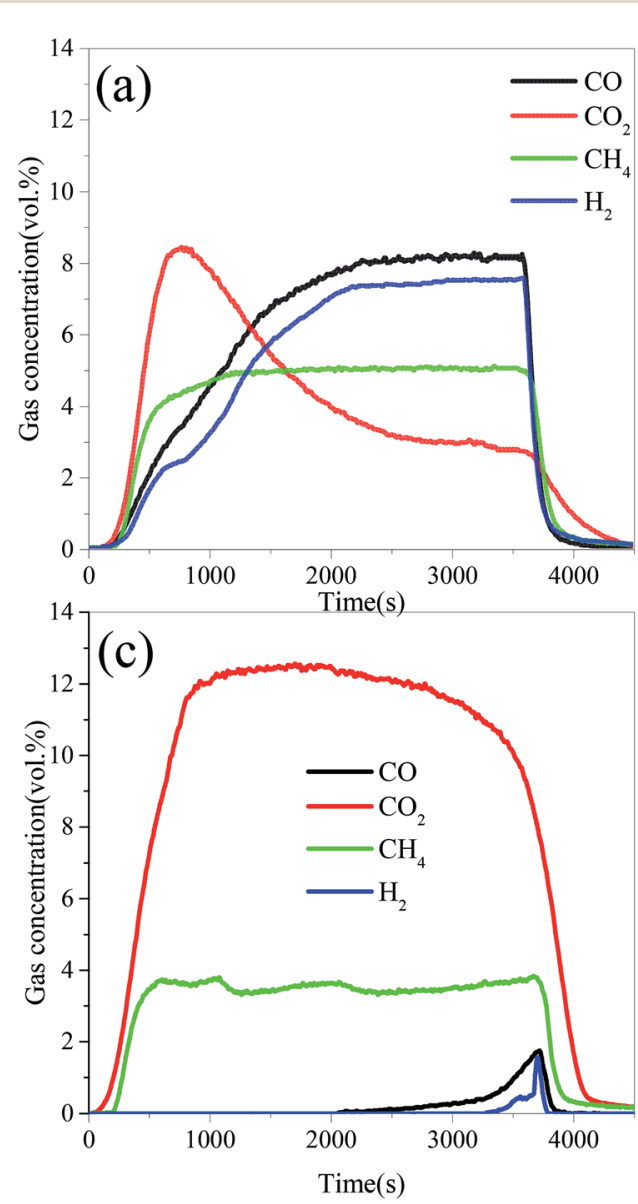

\subsection{Characterization technologies of the OCs}

An X'Pert PRO diffractometer (X'Pert PRO, PANalytical B.V.) equipped with a $\mathrm{Cu} \mathrm{K} \alpha$ radiation source ( $40 \mathrm{kV}$ and $40 \mathrm{~mA}$ ) was used to obtain X-ray diffraction (XRD) patterns of the OCs. The OCs were scanned at a rate of $2^{\circ} \mathrm{min}^{-1}$ from $2 \theta=10^{\circ}$ to $80^{\circ}$ with a scanning step of $0.02^{\circ} . \mathrm{N}_{2}$ adsorption-desorption isotherms and pore-diameter distribution at $-196{ }^{\circ} \mathrm{C}$ were measured using a Micrometrics ASAP 2010 system. The specific surface areas were calculated by the Brunauer-Emmett-Teller (BET) method. The surface morphology of the OCs was obtained using environmental scanning electron microscopy (ESEM; FEI Quanta 200) in conjunction with energy-dispersive X-ray spectroscopy (EDS). $\mathrm{H}_{2}$-TPR was conducted in an AutoChem II 2920. First, the sample (about $0.20 \mathrm{~g}$ ) was heated to $300{ }^{\circ} \mathrm{C}$ at a rate of $10{ }^{\circ} \mathrm{C} \mathrm{min}{ }^{-1}$ in helium (50 $\mathrm{mL} \mathrm{min}{ }^{-1}$ ) and kept for $3 \mathrm{~h}$. After being cooled to $50{ }^{\circ} \mathrm{C}$, helium was replaced by a gas mixture consisting of $10 / 90 \mathrm{H}_{2} / \mathrm{Ar} \mathrm{v} / \mathrm{v} \%$ (50 $\mathrm{mL} \mathrm{min}^{-1}$ ), and the sample was reheated to $900{ }^{\circ} \mathrm{C}$ at a rate of $10^{\circ} \mathrm{C} \mathrm{min}{ }^{-1}$.

\section{Results and discussion}

In the FR, the OCs were reduced by BPG. The reduction time has a great effect on the carbon capture efficiency in the FR and the hydrogen yield in the SR. In this study, the reduction time in the FR increased from $20 \mathrm{~min}$ to $60 \mathrm{~min}$. Both the hydrogen
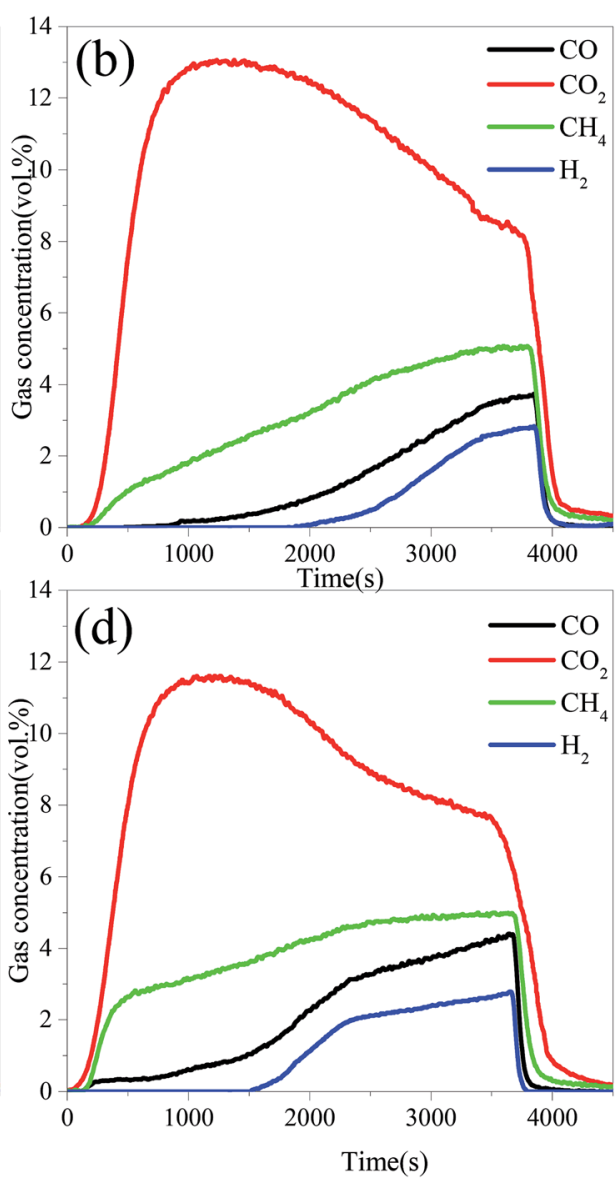

Fig. 3 Gas concentration profiles in the $\mathrm{FR}$ at $900^{\circ} \mathrm{C}$ with different OCs. 
production time in the $\mathrm{SR}$ and the regeneration time in the $\mathrm{AR}$ were fixed at $60 \mathrm{~min}$. The reaction temperatures of the FR, SR, and AR were set at $900{ }^{\circ} \mathrm{C}$.

\subsection{Gas concentration profiles}

Fig. 3 displays the variation trend of the gas concentration with reaction time in the $\mathrm{FR}$ at $900{ }^{\circ} \mathrm{C}$. As can be seen, the main gas components were $\mathrm{CO}_{2}, \mathrm{CO}, \mathrm{CH}_{4}$ and $\mathrm{H}_{2}$ in the FR. At the beginning of the reaction, the reductive gases $\left(\mathrm{CH}_{4}, \mathrm{CO}\right.$ and $\left.\mathrm{H}_{2}\right)$ were oxidized by lattice oxygen. Therefore, the $\mathrm{CO}_{2}$ concentration for all OCs increased quickly. Subsequently, the unreacted reductive gases were measured, and their concentrations increased with the increase in the reduction time. It was implied that the lattice oxygen derived from OCs was consumed gradually with the increasing reaction time. At the same moment, the concentrations of $\mathrm{CO}_{2}$ for all three modified OCs were higher than that for the iron ore, while the concentrations of $\mathrm{CH}_{4}$, $\mathrm{CO}$ and $\mathrm{H}_{2}$ showed the opposite tendency. These results indicated that the presence of the metal oxides significantly enhanced the reactivity of the iron ore. For the same modified OC, the concentration of $\mathrm{CH}_{4}$ in the FR was the highest, followed by $\mathrm{CO}$, and $\mathrm{H}_{2}$ was the lowest. In fact, the concentrations of $\mathrm{CO}$ and $\mathrm{H}_{2}$ in BPG were higher than that of $\mathrm{CH}_{4}$. These results indicated that the selectivity of the modified iron ore OCs toward the three reductive gases (namely $\mathrm{CO}, \mathrm{H}_{2}$ and $\mathrm{CH}_{4}$ ) follow the order of $\mathrm{H}_{2}>\mathrm{CO}>\mathrm{CH}_{4}$. This result was consistent with the reduction rate of $\mathrm{Fe}_{2} \mathrm{O}_{3}$ in the different reductive gases. ${ }^{\mathbf{1 9 , 3 4 , 3 5}}$ It was noted that the NiO-iron ore had the lowest concentration of $\mathrm{CO}$ and $\mathrm{H}_{2}$, and the $\mathrm{CuO}$-iron ore exhibited the lowest $\mathrm{CH}_{4}$ concentration, indicating that the NiO-iron ore exhibited the highest selectivity toward $\mathrm{CO}$ and $\mathrm{H}_{2}$. The CuOiron ore had the highest selectivity toward $\mathrm{CH}_{4}$.

The OCs were reduced by BPG for $60 \mathrm{~min}$ at $900{ }^{\circ} \mathrm{C}$ in the FR. After that, the steam was introduced into the reactor to produce hydrogen in the SR. Fig. 4 presents the gas concentration profiles in the SR. The $\mathrm{H}_{2}$ concentration for the three OCs increased quickly, and then decreased. The instantaneous maximum $\mathrm{H}_{2}$ concentration for the three modified iron ores was higher than $60 \%$, while the peak value of the $\mathrm{H}_{2}$ concentration for iron ore was just $38.75 \%$ under the same conditions. It was noted that a small amount of $\mathrm{CO}$ and $\mathrm{CO}_{2}$ products was detected in the SR. It was attributed to the oxidation of carbon deposited onto the OCs during the reduction stage in the FR. Both $\mathrm{CO}$ and $\mathrm{CH}_{4}$ can form carbon deposits through reactions (R1) and (R2) at relatively high temperatures. The carbon deposits formed on the surface of the OCs in the FR, and then reacted with steam in the $\mathrm{SR}$ to produce carbonaceous gases (R3 and R4), resulting in a decrease in the hydrogen purity.
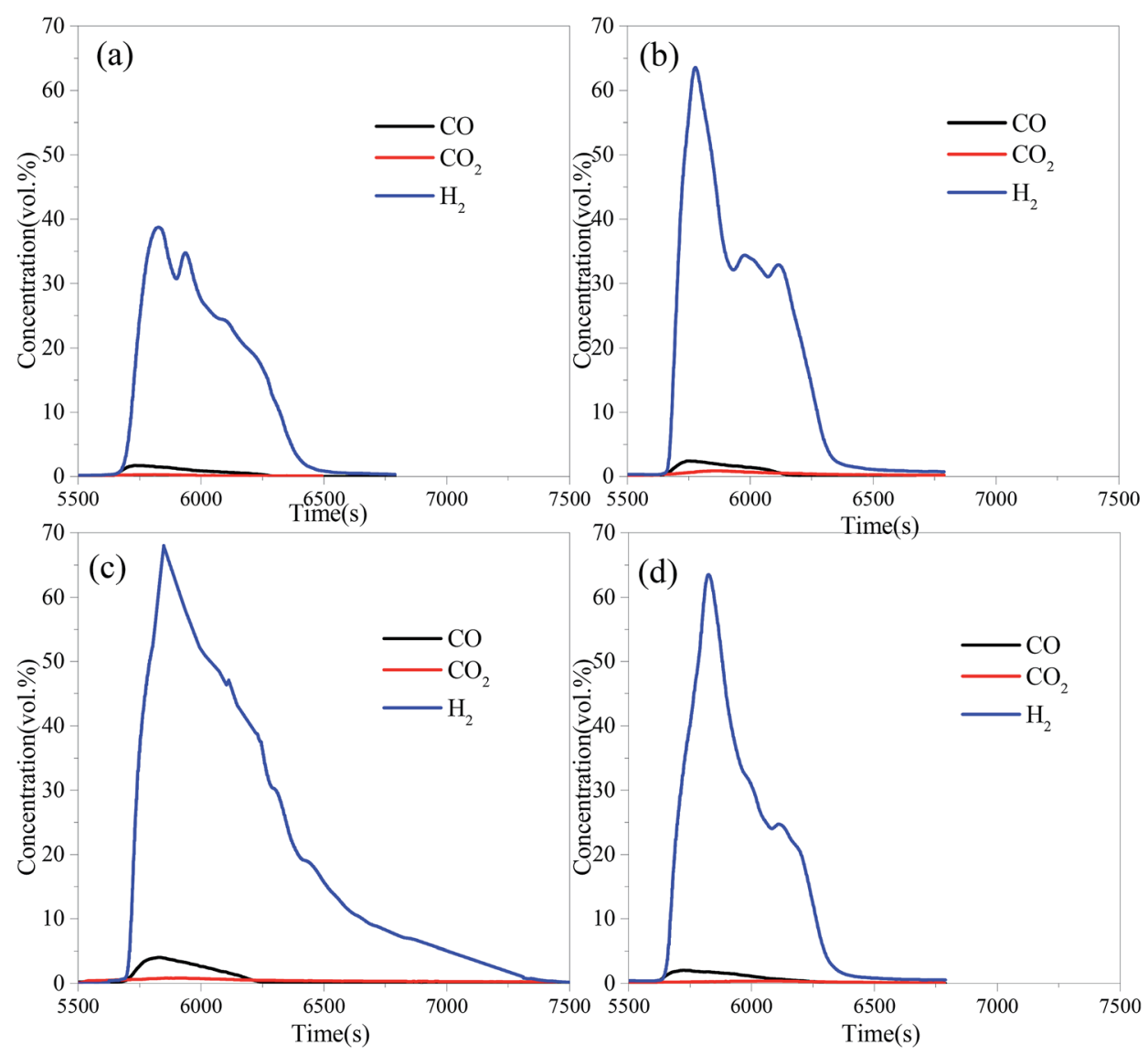

Fig. 4 The gas concentration profiles in the SR with different OCs reduced by BPG for 60 min at $900^{\circ} \mathrm{C}$ : (a) iron ore, (b) CuO-iron ore, (c) NiOiron ore and (d) $\mathrm{CeO}_{2}$-iron ore. 


$$
\begin{gathered}
2 \mathrm{CO} \Leftrightarrow \mathrm{CO}_{2}+\mathrm{C} \\
\mathrm{CH}_{4} \Leftrightarrow 2 \mathrm{H}_{2}+\mathrm{C} \\
\mathrm{C}+\mathrm{H}_{2} \mathrm{O} \Leftrightarrow \mathrm{H}_{2}+\mathrm{CO} \\
\mathrm{C}+2 \mathrm{H}_{2} \mathrm{O} \Leftrightarrow 2 \mathrm{H}_{2}+\mathrm{CO}_{2}
\end{gathered}
$$

\subsection{Effects of the reduction time in FR}

3.2.1 Carbon capture efficiency. Fig. 5 shows the carbon capture efficiency in the FR for four OCs at $900{ }^{\circ} \mathrm{C}$ under different reduction times. In the initial stage, the carbon capture efficiency for the four OCs was close to $100 \%$. The carbon capture efficiency decreased with the increase of the reduction time. The carbon capture efficiency for the CuO-iron ore, $\mathrm{NiO}-$ iron ore, $\mathrm{CeO}_{2}$-iron ore and iron ore at $97.39 \%$, $91.02 \%, 91.01 \%$ and $86.59 \%$, respectively, were observed at a reaction time of $10 \mathrm{~min}$. These values were then decreased to $75.90 \%, 80.30 \%, 65.61 \%$ and $33.75 \%$ at the reduction time of $60 \mathrm{~min}$. At the beginning of the reaction, $\mathrm{Fe}_{2} \mathrm{O}_{3}$ was reduced readily into $\mathrm{Fe}_{3} \mathrm{O}_{4}$ by reductive gases, which favored the production of $\mathrm{CO}_{2}$ and $\mathrm{H}_{2} \mathrm{O}$. With the increase in the reaction time, the conversion from $\mathrm{Fe}_{3} \mathrm{O}_{4}$ to $\mathrm{FeO}$ or $\mathrm{Fe}$ became difficult, and the reductive gases also were not converted completely into $\mathrm{CO}_{2}$ and $\mathrm{H}_{2} \mathrm{O}$. Miguel et al. ${ }^{36}$ have reported that iron ore can fully convert the simulated syngas at $880{ }^{\circ} \mathrm{C}$, regardless of the $\mathrm{CO} / \mathrm{H}_{2}$ ratio used. However, lower conversion rates were observed with methane-containing fuels. Thus, it was inferred that the $\mathrm{CH}_{4}$ in BPG was the main factor for the reduction of CGE. The CuO-iron ore exhibited the highest carbon capture efficiency until a reduction time around at $50 \mathrm{~min}$. Compared with the $\mathrm{NiO}$-iron ore and $\mathrm{CeO}_{2}$-iron ore, the $\mathrm{CuO}$-iron ore was more suitable for the application of the chemical looping combustion process for carbon capture. It was noted that there

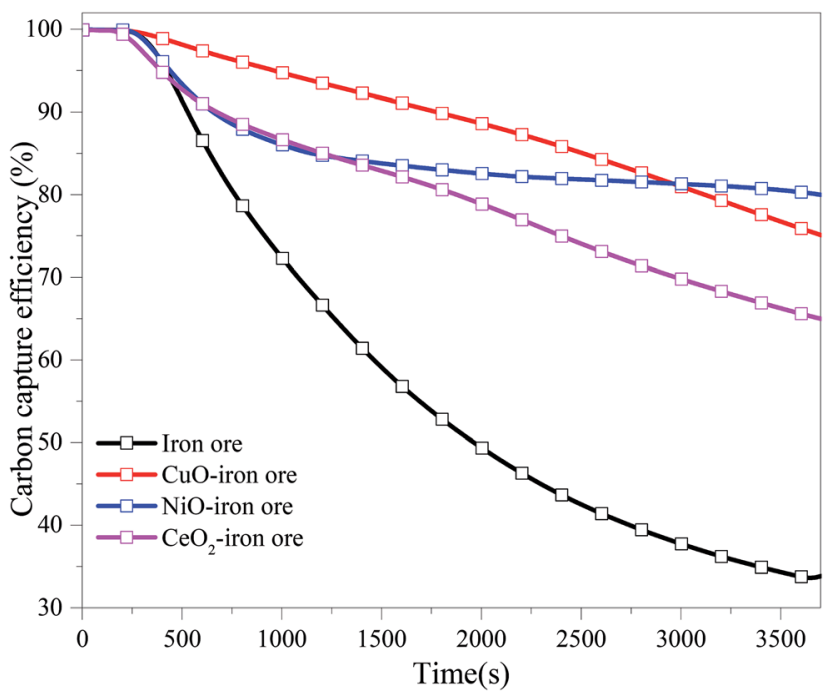

Fig. 5 The variation trend of the carbon capture efficiency (CGE) with reduction time in $\mathrm{FR}$ at $900^{\circ} \mathrm{C}$. was a slight decrease in the carbon capture efficiency for the $\mathrm{NiO}-$ iron ore OCs from $20 \mathrm{~min}$ to $60 \mathrm{~min}$. The carbon capture efficiency for the $\mathrm{CeO}_{2}$-iron ore was the lowest among the three modified iron ores at the same time. However, it was still much higher than that for iron ore. Compared with $\mathrm{CuO}$ and $\mathrm{NiO}$, the oxygen transport capacity of $\mathrm{CeO}_{2}$ can be negligible. Although the $\mathrm{CeO}_{2}$-iron ore had a lower mass fraction of $\mathrm{Fe}_{2} \mathrm{O}_{3}$ than that of iron ore, the presence of $\mathrm{CeO}_{2}$ promoted the reactivity of $\mathrm{Fe}_{2} \mathrm{O}_{3}$.

3.2.2 Hydrogen yield. Fig. 6 shows the hydrogen yields for the four OCs under different reaction times. As the reaction time increased, the hydrogen yields for all OCs increased. This is mainly due to the fact that the reduction degree of the OCs was deepened with increasing reduction time in the FR. The maximum theoretical hydrogen yield of the iron ore was $14.36 \mathrm{mmol} \mathrm{g}^{-1}$; in this condition, $\mathrm{Fe}_{2} \mathrm{O}_{3}$ in the iron ore was reduced completely into $\mathrm{Fe}$. The theoretical hydrogen yield decreased to $3.59 \mathrm{mmol} \mathrm{g}^{-1}$ when the $\mathrm{Fe}_{2} \mathrm{O}_{3}$ in iron ore was reduced completely into $\mathrm{FeO}$. When the reduction time was $20 \mathrm{~min}$, a maximum hydrogen yield of $1.54 \mathrm{mmol} \mathrm{g}^{-1}$ was obtained for the iron ore. Thus, the $\mathrm{Fe}_{2} \mathrm{O}_{3}$ was reduced to $\mathrm{FeO}$ and $\mathrm{Fe}_{3} \mathrm{O}_{4}$ after $20 \mathrm{~min}$. The hydrogen yields of the NiO-iron ore, CuO-iron ore, $\mathrm{CeO}_{2}$-iron ore were $4.65 \mathrm{mmol} \mathrm{g}^{-1}, 5.36 \mathrm{mmol}$ $\mathrm{g}^{-1}$ and $3.96 \mathrm{mmol} \mathrm{g}^{-1}$ after $20 \mathrm{~min}$, respectively, indicating that $\mathrm{Fe}_{2} \mathrm{O}_{3}$ was reduced to $\mathrm{FeO}$ and Fe. Compared with the modified iron ore OCs, the iron ore exhibited a lower hydrogen yield under the same conditions, indicating that the presence of metal oxides improved the reactivity and enhanced the reduction degree of the iron ore. The hydrogen yields for the four OCs all decreased in the following order: $\mathrm{NiO}$-iron ore $>\mathrm{CuO}$-iron ore $>\mathrm{CeO}_{2}$-iron ore $>$ iron ore. The maximum hydrogen yields of the NiO-iron ore, $\mathrm{CuO}$-iron ore, $\mathrm{CeO}_{2}$-iron ore and iron ore were $11.46 \mathrm{mmol} \mathrm{g}^{-1}, 10.84 \mathrm{mmol} \mathrm{g}^{-1}, 10.44 \mathrm{mmol} \mathrm{g}^{-1}$ and $5.39 \mathrm{mmol} \mathrm{g}^{-1}$ at the reaction time of $60 \mathrm{~min}$, respectively.

In general, more hydrogen can be obtained by increasing the reduction time in the FR. However, the longer the reduction

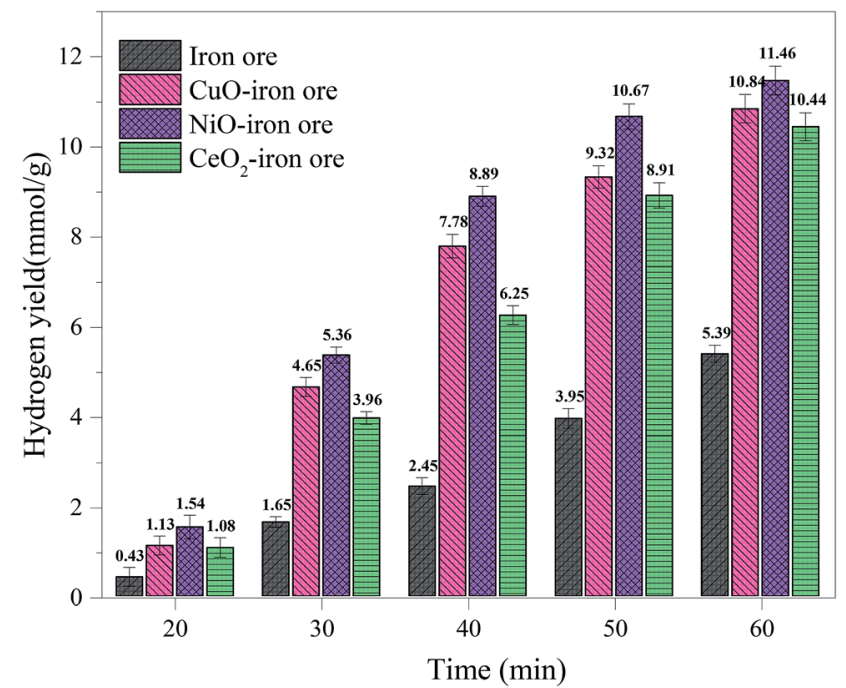

Fig. 6 The hydrogen yield in SR at $900{ }^{\circ} \mathrm{C}$ with different reduction times in FR. 
time, the lower was the carbon capture efficiency. According to the comprehensive analysis of the hydrogen yield and carbon capture efficiency, it was concluded that the reduction time at $\sim 40 \mathrm{~min}$ in the $\mathrm{FR}$ at $900{ }^{\circ} \mathrm{C}$ was an optimal value. Under this condition, the hydrogen yields of the four OCs in the SR were $8.89 \mathrm{mmol} \mathrm{g}^{-1}, 7.78 \mathrm{mmol} \mathrm{g}^{-1}, 6.25 \mathrm{mmol} \mathrm{g}^{-1}$ and $2.45 \mathrm{mmol}$ $\mathrm{g}^{-1}$ for the NiO-iron ore, $\mathrm{CuO}$-iron ore, $\mathrm{CeO}_{2}$-iron ore and iron ore, respectively. In addition, the corresponding carbon capture efficiencies in the FR were $83.29 \%, 82.54 \%$, $70.97 \%$ and $40.46 \%$.

\subsection{Effects of the reaction temperatures in FR}

Temperature plays a key role in all chemical looping processes. In the $\mathrm{CLH}$ production process, temperature directly affected the carbon capture efficiency in the FR, hydrogen yield and purity in the SR and the regeneration rate of the OCs in the AR. In this section, the temperature effects were investigated. In each run, the reaction temperatures of the FR, SR and AR were identical. The reaction temperatures varied in the range of 800 $1000{ }^{\circ} \mathrm{C}$ with an interval of $50{ }^{\circ} \mathrm{C}$. The reduction time of the OCs in the FR by BPG was $40 \mathrm{~min}$, the oxidation time of the OCs in the SR by steam was $60 \mathrm{~min}$ and the regeneration time of the OCs in the AR by air was $60 \mathrm{~min}$.

3.3.1 Carbon capture efficiency. As shown in Fig. 7, with the increase of temperature from $800{ }^{\circ} \mathrm{C}$ to $1000{ }^{\circ} \mathrm{C}$, the carbon capture efficiencies for the iron ore, $\mathrm{CuO}$-iron ore, NiO-iron ore and $\mathrm{CeO}_{2}$-iron ore increased from $32.11 \%, 76.65 \%, 70.66 \%$ and $62.86 \%$ to $48.69 \%, 88.33 \%, 89.19 \%$ and $80.65 \%$, respectively. Compared with the $\mathrm{CuO}$-iron ore and NiO-iron ore, the $\mathrm{CeO}_{2}-$ iron ore exhibited lower carbon capture efficiency in the whole temperature range. It was mainly attributed to the fact that the $\mathrm{CuO}$-iron ore and $\mathrm{NiO}$-iron ore provided more lattice oxygen for syngas combustion in comparison to the $\mathrm{CeO}_{2}$-iron ore. The carbon capture efficiency for the $\mathrm{CuO}$-iron ore was higher than that for NiO-iron ore at $800{ }^{\circ} \mathrm{C}$ and $850{ }^{\circ} \mathrm{C}$, while an opposite tendency was observed when the reaction temperature reached above $900{ }^{\circ} \mathrm{C}$. This indicated that the activity of the CuO-iron

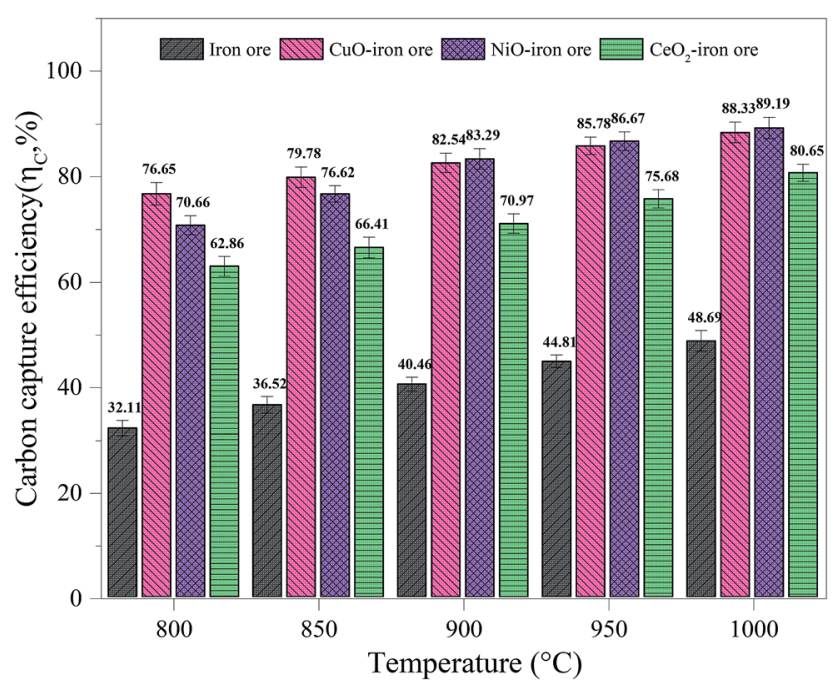

Fig. 7 The carbon capture efficiency in FR at different temperatures. ore at a lower temperature was higher than that of the NiO-iron ore. It might be attributable to the fact that $\mathrm{CuFe}_{2} \mathrm{O}_{4}$ was more readily reduced than $\mathrm{NiFe}_{2} \mathrm{O}_{4}$ at a low temperature. ${ }^{37,38}$

3.3.2 Hydrogen yield and purity. Fig. 8 shows the hydrogen yield at different reaction temperatures with the reduction time of $40 \mathrm{~min}$ in the FR. The hydrogen yield, $1.54 \mathrm{mmol} \mathrm{g}^{-1}$, $1.03 \mathrm{mmol} \mathrm{g}^{-1}$ and $0.88 \mathrm{mmol} \mathrm{g}^{-1}$, for the NiO-iron ore, $\mathrm{CuO}-$ iron ore and $\mathrm{CeO}_{2}$-iron ore, respectively, were obtained at $800{ }^{\circ} \mathrm{C}$. The temperature not only affected the reaction reactivity of the OCs with fuel, but also affected the reaction reactivity of the OCs with steam. With the reaction temperature increased to $900{ }^{\circ} \mathrm{C}$, the hydrogen yields at $8.89 \mathrm{mmol} \mathrm{g}^{-1}, 7.78 \mathrm{mmol} \mathrm{g}^{-1}$ and $6.25 \mathrm{mmol} \mathrm{g}^{-1}$ for the NiO-iron ore, $\mathrm{CuO}$-iron ore and $\mathrm{CeO}_{2}$-iron ore were observed, respectively. When the temperature was higher than $900{ }^{\circ} \mathrm{C}$, the effect of increasing the temperature on the hydrogen yield was not obvious. It was attributed that the reduction from $\mathrm{FeO}$ to $\mathrm{Fe}$ was difficult even at a high temperature. The highest hydrogen yields of $11.23 \mathrm{mmol}$ $\mathrm{g}^{-1}, 11.03 \mathrm{mmol} \mathrm{g}^{-1}$ and $9.89 \mathrm{mmol} \mathrm{g}^{-1}$, for the NiO-iron ore, $\mathrm{CuO}$-iron ore and $\mathrm{CeO}_{2}$-iron ore were obtained at $1000{ }^{\circ} \mathrm{C}$ for $60 \mathrm{~min}$, respectively.

Generally, a high concentration of hydrogen can be obtained in the steam-iron process. In fact, small amounts of carbonaceous gas were observed in the SR, which were derived from the reactions between the deposited carbon and $\mathrm{H}_{2} \mathrm{O}$. The carbon deposition not only decreased the reactivity of the OCs, but also contaminated the hydrogen produced in the steam oxidation stage, leading to the reduction in the hydrogen purity. Fig. 9 shows the varying trend of the hydrogen purity at different reaction temperatures. With the increase of temperatures of the $\mathrm{FR}$, the hydrogen purity decreased. It was attributed to the fact that the high temperature enhanced the reactivity of OCs and promoted the subsequent BPG oxidation process. Therefore, the carbon deposition on the surface of the OC increased. At the same temperature, the hydrogen purity of the iron ore was

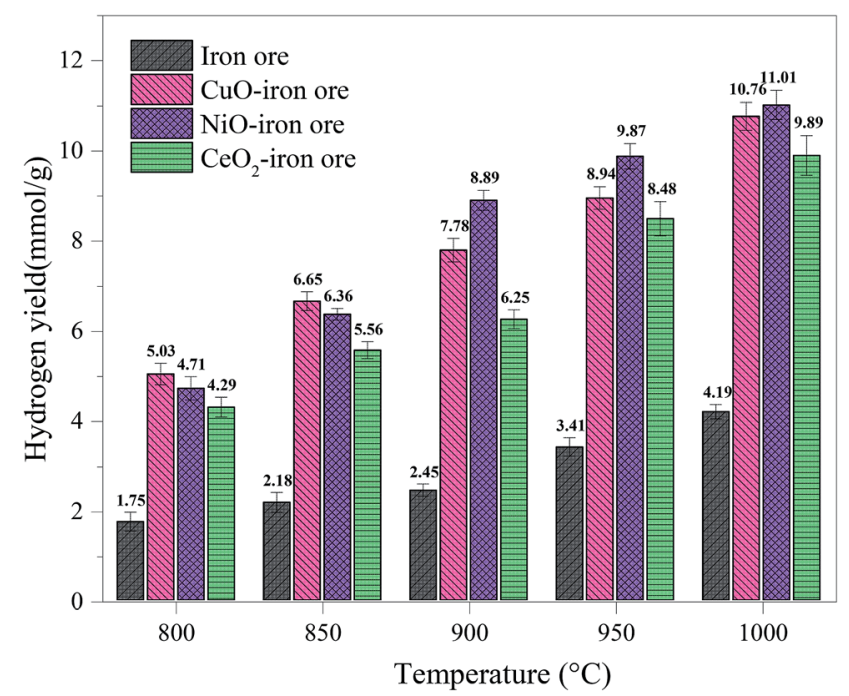

Fig. 8 Effect of the reduction temperature in FR on the hydrogen yield in $\mathrm{SR}$. 


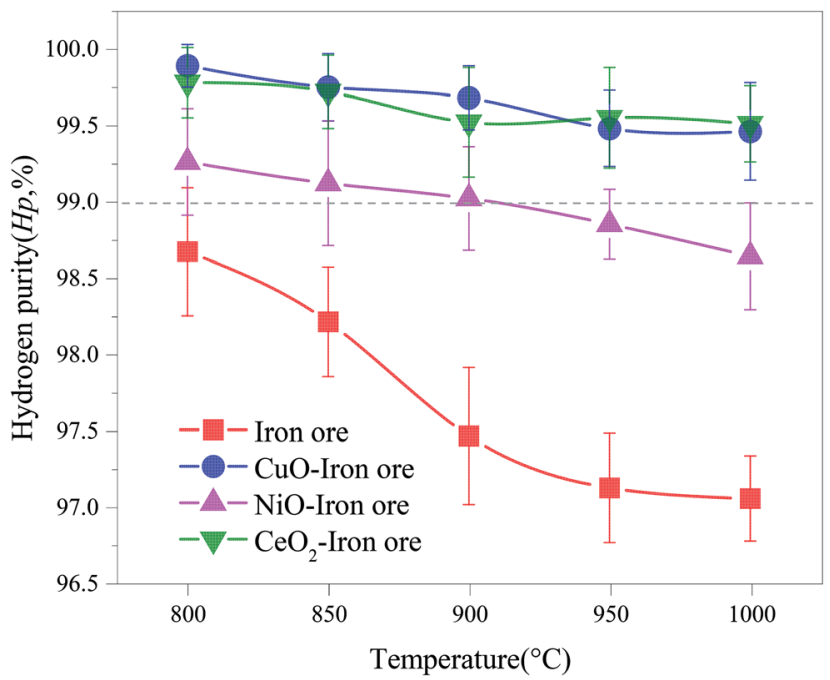

Fig. 9 Effect of the reduction temperature in FR on the hydrogen purity in SR.

lowest. This result confirmed that the addition of $\mathrm{CuO}, \mathrm{NiO}$ and $\mathrm{CeO}_{2}$ played a role in inhibiting the carbon deposition. A hydrogen purity of $>99.0 \%$ was achieved in the temperature range of $800-1000{ }^{\circ} \mathrm{C}$ using both $\mathrm{CuO}$-iron ore and $\mathrm{CeO}_{2}$-iron ore as the OC. The hydrogen purity for the NiO-iron ore decreased from $99.26 \%$ at $800{ }^{\circ} \mathrm{C}$ to $98.64 \%$ at $1000{ }^{\circ} \mathrm{C}$. Zeng et $a .^{39}$ reported that the hydrogen yield and hydrogen purity varied from $1.66 \mathrm{mmol}$ and $99 \%$ from to $2.81 \mathrm{mmol}$ and $84 \%$, respectively, when using a bio-oil heavy fraction as fuel and $\mathrm{Fe}_{2} \mathrm{O}_{3} / \mathrm{Al}_{2} \mathrm{O}_{3}$ (60 wt\%/40 wt\%) as the OC at $950{ }^{\circ} \mathrm{C}$. Both the $\mathrm{CuO}$-iron ore and $\mathrm{CeO}_{2}$-iron ore showed higher anti-coking ability compared with the $\mathrm{NiO}$-iron ore. It was attributed to the fact that the metallic Fe and $\mathrm{Ni}$ in the deeply reduced OC have good catalytic performances for the $\mathrm{CH}_{4}$ decomposition reaction (R2).

\subsection{Cyclic tests}

In order to investigate the cyclic performance of the modified iron ore OCs, a total of 10 cycles were conducted in the fluidized bed reactor. The temperatures of the FR, SR and AR were $900{ }^{\circ} \mathrm{C}$. The reduction time in the $\mathrm{FR}$, steam oxidation time in the SR and regeneration time in the AR were $40 \mathrm{~min}, 60 \mathrm{~min}$ and 60 min, respectively. As shown in Fig. 10, the carbon capture efficiency and hydrogen yield for the CuO-iron ore OC decreased from $82.54 \%$ and $7.78 \mathrm{mmol} \mathrm{g}^{-1}$ to $75.09 \%$ and $6.38 \mathrm{mmol} \mathrm{g}^{-1}$ with increasing cycles, respectively. The carbon capture efficiency increased slightly to $78.14 \%$ in a cyclic test of the $\mathrm{CeO}_{2}$-iron ore, and there was no significant trend change for the hydrogen yield. After 10 cycles, a hydrogen yield of $6.33 \mathrm{mmol} \mathrm{g}^{-1}$ was observed for the $\mathrm{CeO}_{2}$-iron ore. The carbon capture efficiency and hydrogen yield for the NiO-iron ore both decreased slightly, and achieved $79.51 \%$ and $8.89 \mathrm{mmol} \mathrm{g}^{-1}$ at the $10^{\text {th }}$ cycle, respectively. These results indicated that the $\mathrm{CeO}_{2}$-iron ore and NiO-iron ore had good cyclic performances, while the reactivity of the CuO-iron ore decreased with an increase in the number cycle.

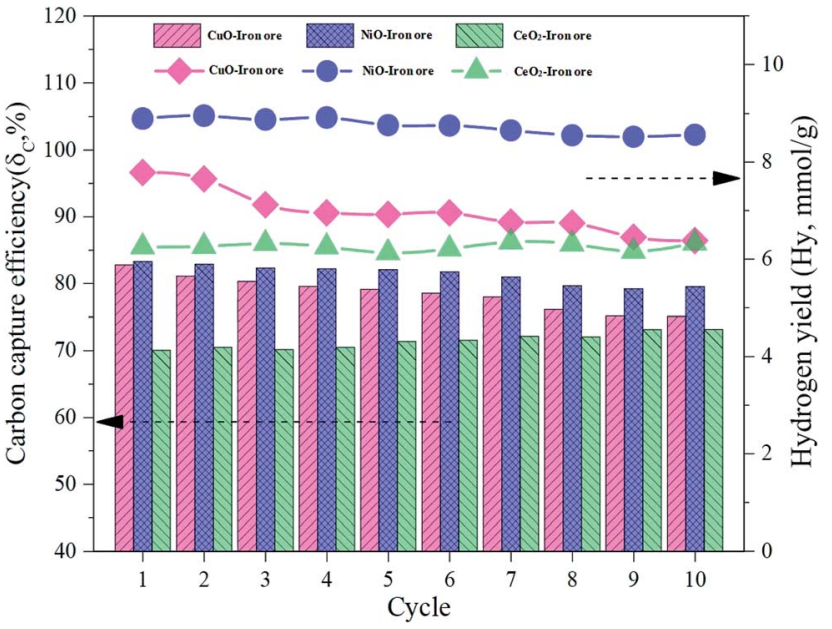

Fig. 10 The various trends of the carbon capture efficiency and hydrogen yield in the cyclic test.

\subsection{Characterization of the OCs}

3.5.1 $\mathbf{H}_{2}$-TPR. The $\mathrm{H}_{2}$-TPR profiles of different fresh OCs were processed using the peak-fitting software. The results are shown in Fig. 11. The different colored curves present the reduction of different species. Three peaks at $c a .495{ }^{\circ} \mathrm{C}, 630{ }^{\circ} \mathrm{C}$ and $770{ }^{\circ} \mathrm{C}$ were observed for the $\mathrm{H}_{2}$-TPR profiles of the fresh
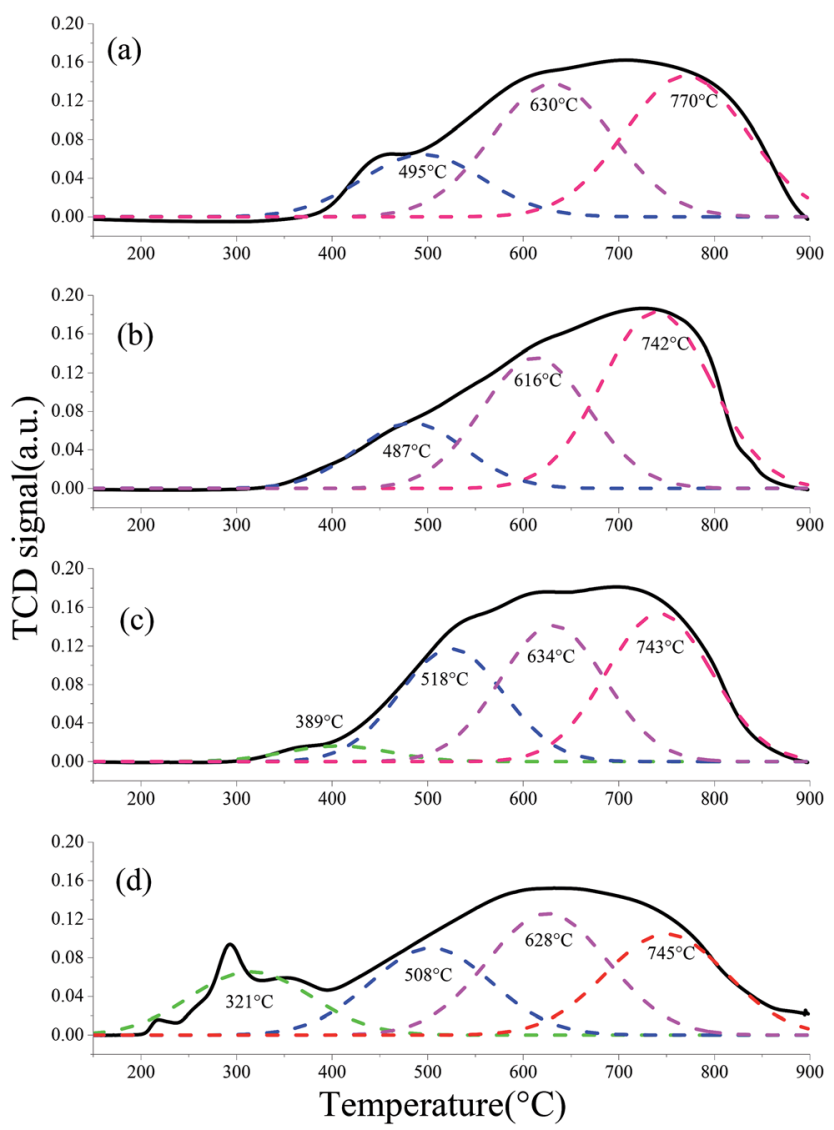

Fig. $11 \mathrm{H}_{2}$-TPR profiles of the fresh OCs: (a) iron ore, (b) $\mathrm{CeO}_{2}$-iron ore, (c) NiO-iron ore and (d) $\mathrm{CuO}$-iron ore. 
iron ore, which were assigned to the reduction of $\mathrm{Fe}_{2} \mathrm{O}_{3}, \mathrm{Fe}_{3} \mathrm{O}_{4}$ and $\mathrm{FeO}$, respectively. Similar results were published by $\mathrm{Gu}$ et al. ${ }^{40}$ Similarly, the fresh $\mathrm{CeO}_{2}$-iron ore exhibited three reduction peaks. The first peak at $c a .470{ }^{\circ} \mathrm{C}$ was attributed to the reduction of residual surface $\mathrm{Fe}^{3+}$. However, the reduction peaks for the $\mathrm{CeO}_{2}$-iron ore shifted to lower temperatures compared with the peaks for the iron ore, indicating that the $\mathrm{CeO}_{2}$ additive decreased the reduction temperature of the iron ore. When the iron ore was modified by $\mathrm{NiO}$ and $\mathrm{CuO}$, reduction peaks at $389{ }^{\circ} \mathrm{C}$ and $321{ }^{\circ} \mathrm{C}$ appeared and were assigned to the reduction of free $\mathrm{NiO}$ and $\mathrm{CuO}$ located on the surface, respectively. Compared with the iron ore, two peaks with larger peak areas were observed at $518{ }^{\circ} \mathrm{C}$ for the $\mathrm{NiO}$-iron ore and at $508{ }^{\circ} \mathrm{C}$ for the $\mathrm{CuO}$-iron ore, assigned to the reduction of $\mathrm{NiFe}_{2} \mathrm{O}_{4}$ and $\mathrm{CuFe}_{2} \mathrm{O}_{4}$. Similar results were observed in our previous work. ${ }^{37}$ The peaks at about $630{ }^{\circ} \mathrm{C}$ were similar for the NiO-iron ore, CuO-iron ore and iron ore, indicating that the additives had a small influence on the reduction of $\mathrm{Fe}_{3} \mathrm{O}_{4}$. Similar to that of the $\mathrm{CeO}_{2}$-iron ore, the peaks at $743{ }^{\circ} \mathrm{C}$ for the $\mathrm{NiO}$-iron ore and at $745{ }^{\circ} \mathrm{C}$ for the $\mathrm{CuO}$-iron ore verified that the reduction temperature of the iron ore was decreased by introducing metallic oxides.

3.5.2 XRD. The crystal phases of the OCs at different reaction stages are listed in Table 2. The main components of the calcined iron ore were $\mathrm{Fe}_{2} \mathrm{O}_{3}$ and $\mathrm{SiO}_{2}$. For the fresh modified iron ore OCs, $\mathrm{Fe}_{2} \mathrm{O}_{3}$ and the metal oxides (namely $\mathrm{CuO}$, NiO and $\mathrm{CeO}_{2}$ ) were correspondingly presented. Generally, $\mathrm{CuO}$ and $\mathrm{NiO}$ had higher oxygen transport capacities than $\mathrm{Fe}_{2} \mathrm{O}_{3}$ in the chemical looping process, and more lattice oxygen derived from $\mathrm{CuO}$ and $\mathrm{NiO}$ was beneficial to enhancing the syngas conversion. Additionally, $\mathrm{CuFe}_{2} \mathrm{O}_{4}$ and $\mathrm{NiFe}_{2} \mathrm{O}_{4}$ with spinel structures $\left(\mathrm{AB}_{2} \mathrm{O}_{4}\right)$ were observed in the $\mathrm{CuO}$-iron ore and $\mathrm{NiO}$-iron ore samples, respectively. Intensive references demonstrated that the presence of a spinel structure improved the reduction kinetics and enhanced the reducibility of $\mathrm{Fe}_{2} \mathrm{O}_{3}{ }^{\mathbf{1 4 , 4 1 - 4 4}}$

In the reduced samples, the unmodified iron ore was mainly reduced into $\mathrm{FeO}$ and $\mathrm{Fe}_{3} \mathrm{O}_{4}$; the $\mathrm{CuO}$-iron ore was reduced into $\mathrm{Cu}, \mathrm{FeO}$ and $\mathrm{Fe}$; the NiO-iron ore was reduced into $\mathrm{Ni}, \mathrm{FeO},(\mathrm{Ni}$, $\mathrm{Fe}$ ) and $\mathrm{Fe}$; while the $\mathrm{CeO}_{2}$-iron ore was reduced into $\mathrm{FeO}$, $\mathrm{CeFeO}_{3}$ and $\mathrm{Fe}$. The reduction of $\mathrm{Fe}_{2} \mathrm{O}_{3}$ to $\mathrm{Fe}_{3} \mathrm{O}_{4}$ did not contribute to the production of hydrogen in the oxidation step. Therefore, the unmodified iron ore displayed the lowest hydrogen yield. The $\mathrm{Fe}_{3} \mathrm{O}_{4}$ phase was not observed in the modified OCs after the reduction reaction. These results suggested that the metal oxides promote the reduction of $\mathrm{Fe}_{3} \mathrm{O}_{4}$. It was noted that $\mathrm{CeFeO}_{3}$ with a perovskite structure $\left(\mathrm{ABO}_{3}\right)$ was detected in the reduced sample of the $\mathrm{CeO}_{2}$-iron ore OC. Many
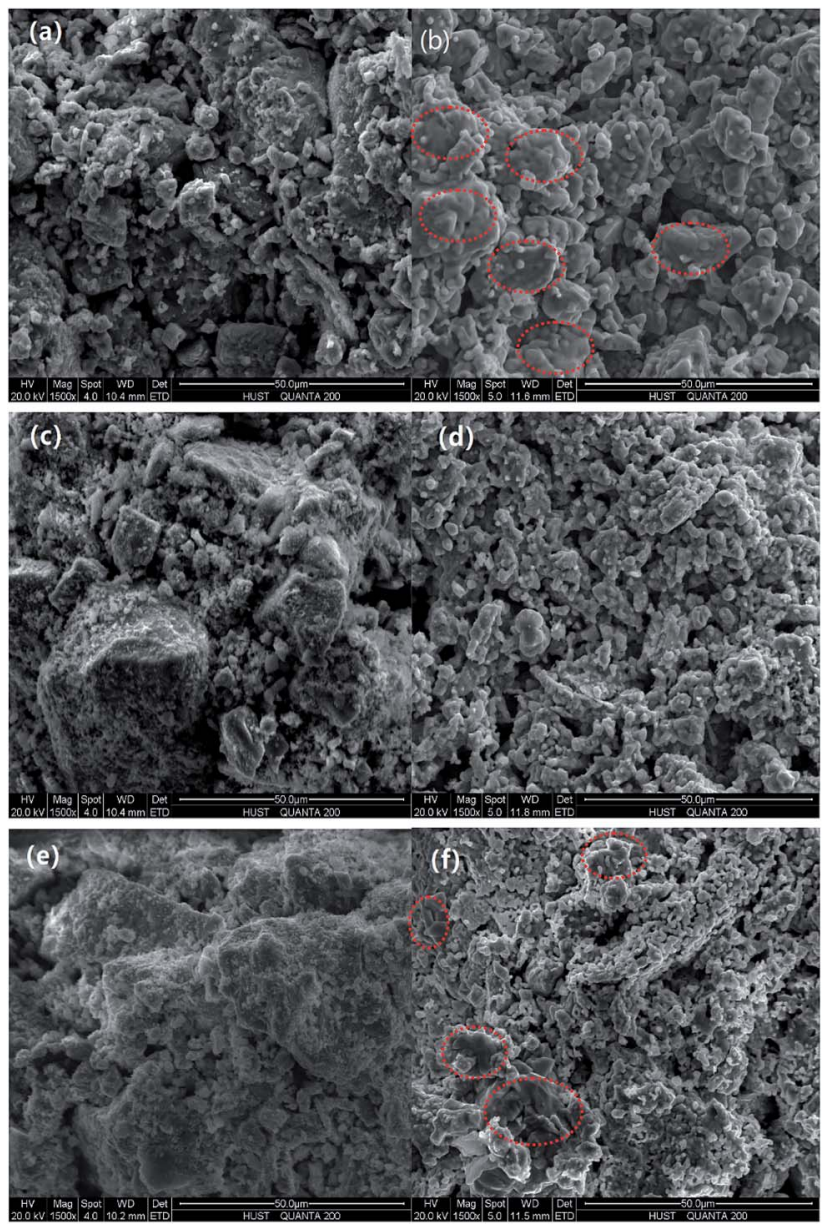

Fig. 12 The surface morphology of the three modified OCs particles: (a), (c) and (e) are the fresh $\mathrm{CuO}$-iron ore, $\mathrm{NiO}$-iron ore and $\mathrm{CeO}_{2}-$ iron ore, respectively; (b), (d) and (f) are the $\mathrm{CuO}$-iron ore, NiO-iron ore and $\mathrm{CeO}_{2}$-iron ore after 10 cycles, respectively.

researchers also reported that $\mathrm{Fe}_{2} \mathrm{O}_{3}$, together with $\mathrm{CeO}_{2}$, forms a perovskite-type $\mathrm{CeFeO}_{3}$, which improved the reversibility of the $\mathrm{Fe}_{2} \mathrm{O}_{3}$ redox reaction. ${ }^{\mathbf{4 0 , 4 5 - 4 7}} \mathrm{Gu}$ et al. ${ }^{\mathbf{4 0}}$ reported that the abundant $\mathrm{Ce}^{3+}$ ions in $\mathrm{CeFeO}_{3}$ might act as a catalyst to enhance the reducibility of the Ce and Fe oxides. Zhu et al. ${ }^{\mathbf{4 7}}$ found that the formation of $\mathrm{CeFeO}_{3}$ enhanced the oxygen mobility of the $\mathrm{CeO}_{2}-\mathrm{Fe}_{2} \mathrm{O}_{3} \mathrm{OC}$.

After the steam oxidation process, the Fe species contained in the OCs were mainly oxidized into $\mathrm{Fe}_{3} \mathrm{O}_{4}$ to produce hydrogen. When the $\mathrm{CeO}_{2}$-iron ore was used as an $\mathrm{OC}, \mathrm{CeFeO}_{3}$ remained after the steam oxidation process. Thus, the $\mathrm{Fe}$

Table 2 The component of crystalline phase of OCs in different reaction stages

\begin{tabular}{|c|c|c|c|c|c|}
\hline Iron ore & $\mathrm{Fe}_{2} \mathrm{O}_{3}$ & $\mathrm{FeO}, \mathrm{Fe}_{3} \mathrm{O}_{4}$ & $\mathrm{Fe}_{3} \mathrm{O}_{4}$ & $\mathrm{Fe}_{2} \mathrm{O}_{3}$ & $\mathrm{Fe}_{2} \mathrm{O}_{3}$ \\
\hline CuO-iron ore & $\mathrm{Fe}_{2} \mathrm{O}_{3}, \mathrm{CuO}, \mathrm{CuFe}_{2} \mathrm{O}_{4}$ & $\mathrm{FeO}, \mathrm{Fe}, \mathrm{Cu}$ & $\mathrm{Cu}, \mathrm{Fe}_{3} \mathrm{O}_{4}$ & $\mathrm{Fe}_{2} \mathrm{O}_{3}, \mathrm{CuFe}_{2} \mathrm{O}_{4}$ & $\mathrm{Fe}_{2} \mathrm{O}_{3}, \mathrm{CuFe}_{2} \mathrm{O}_{4}$ \\
\hline CeO-iron ore & $\mathrm{Fe}_{2} \mathrm{O}_{3}, \mathrm{CeO}_{2}$ & $\mathrm{FeO}, \mathrm{CeFeO}_{3}, \mathrm{Fe}$ & $\mathrm{Fe}_{3} \mathrm{O}_{4}, \mathrm{CeFeO}_{3}$ & $\mathrm{Fe}_{2} \mathrm{O}_{3}, \mathrm{CeO}_{2}$ & $\mathrm{Fe}_{2} \mathrm{O}_{3}, \mathrm{CeO}_{2}$ \\
\hline
\end{tabular}


element contained in $\mathrm{CeFeO}_{3}$ was not oxidized by steam to produce hydrogen. This can be used to explain how the $\mathrm{CeO}_{2}-$ iron ore OC had a lower hydrogen yield in comparison with that of the CuO-iron ore and NiO-iron ore OCs.

In the regenerated samples, $\mathrm{Fe}_{3} \mathrm{O}_{4}$ was further oxidized to $\mathrm{Fe}_{2} \mathrm{O}_{3}$ by air in the AR. Both $\mathrm{NiO}$ and $\mathrm{CuO}$ disappeared and instead, $\mathrm{CuFe}_{2} \mathrm{O}_{4}$ and $\mathrm{NiFe}_{2} \mathrm{O}_{4}$ with a spinel structure were observed in the $\mathrm{CuO}$-iron ore and $\mathrm{NiO}$-iron ore OCs, respectively. It was due to the reaction of $\mathrm{NiO}$ and $\mathrm{CuO}$ with the iron ore during the redox cycles. $\mathrm{CeFeO}_{3}$ was oxidized to $\mathrm{CeO}_{2}$ and $\mathrm{Fe}_{2} \mathrm{O}_{3}$ by air. It was reported that $\mathrm{CeFeO}_{3}$ was unstable in an oxidation atmosphere. ${ }^{\mathbf{4 0}}$ Compared with the components of the OCs at the first and tenth cycle, it can be found that the crystal phase of the OCs did not change significantly.

3.5.3 ESEM. Fig. 12 shows the SEM micrographs of the three modified OCs after 10 cycles, and the magnification was 1500 times. The different size particles adhered to the surface of the fresh CuO-iron ore. After 10 cycles, the particles became smooth and stuck together, resulting in the compact areas. This may be due to the presence of the sintering behavior of copper during the cyclic tests. Floccules were observed on the fresh
NiO-iron ore sample surface due to the NiO deposition during the preparation process. The floccules were reduced or even disappeared after 10 cycles and instead, formed more particles on the surface. Similar to the NiO-iron ore sample, the surface of the fresh $\mathrm{CeO}_{2}$-iron ore was almost covered by the flocculent substance. After the cyclic experiments, it presented smaller regular particles. Compared with the NiO-iron ore sample, a slight agglomeration was observed for the $\mathrm{CeO}_{2}$-iron ore after 10 cycles.

3.5.4 EDS. Fig. 13 exhibits the distribution of elements on the surface of the reduced OCs. $\mathrm{Cu}, \mathrm{Ni}$ and Ce were observed on the surfaces of the reduced $\mathrm{CuO}$-iron ore, NiO-iron ore and $\mathrm{CeO}_{2}$-iron ore OCs, respectively. Additionally, some trace elements (C, Ca and $\mathrm{Si}$ ) were also examined. This result indicated the formation of carbon deposition during the reduction reaction. The largest carbon atom content at $12.13 \mathrm{wt} \%$ was observed on the surface of the reduced iron ore. The carbon atom content for the reduced $\mathrm{CuO}$-iron ore, NiO-iron ore and $\mathrm{CeO}_{2}$-iron ore were $7.58 \mathrm{wt} \%, 8.25 \mathrm{wt} \%$ and $7.72 \mathrm{wt} \%$, respectively. The introduction of the metal oxides was beneficial to decreasing the carbon deposition. The carbon deposition
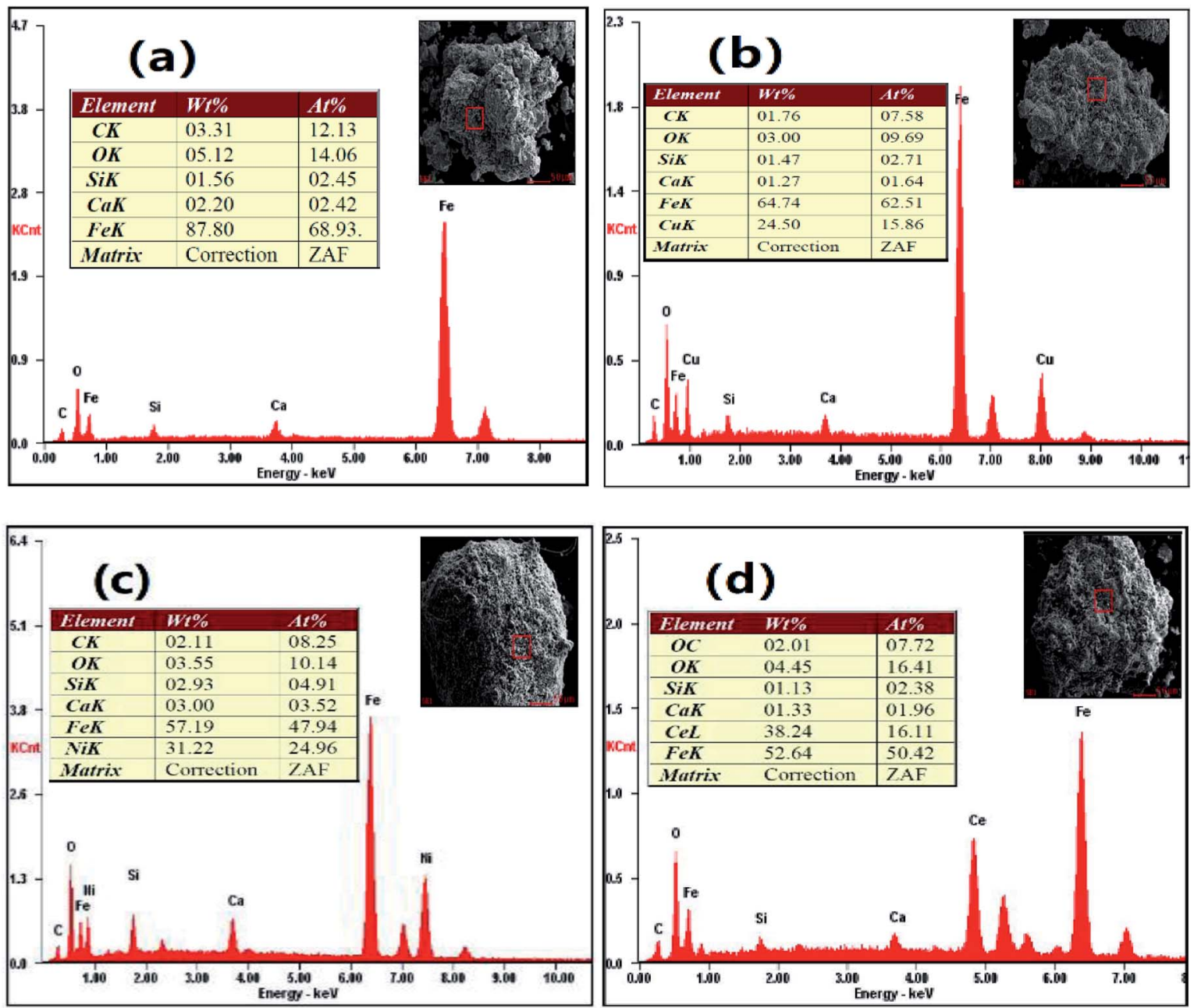

Fig. 13 The distribution of elements on the surface of the OCs after reduction reaction in $\mathrm{FR}$ at $900^{\circ} \mathrm{C}$. (a) Iron ore, (b) $\mathrm{CuO}-\mathrm{iron}$ ore, (c) NiOiron ore and (d) $\mathrm{CeO}_{2}$-iron ore. 
Table 3 The specific areas, total pore volumes, and average pore diameters of the fresh and after 10 cycles OCs

\begin{tabular}{|c|c|c|c|c|c|c|}
\hline Samples & \multicolumn{3}{|l|}{ Fresh OCs } & \multicolumn{3}{|c|}{ OCs after 10 cycles } \\
\hline Iron ore & 0.303 & 7.87 & 0.0015 & 0.201 & 7.33 & 0.0019 \\
\hline CuO-iron ore & 0.746 & 8.46 & 0.0017 & 0.422 & 10.76 & 0.0022 \\
\hline NiO-iron ore & 0.603 & 10.91 & 0.0022 & 0.582 & 11.62 & 0.0016 \\
\hline
\end{tabular}

resistance of the four oxygen carriers decreased in the following order: $\mathrm{CuO}$-iron ore $>\mathrm{CeO}_{2}$-iron ore $>\mathrm{NiO}$-iron ore $>$ iron ore, which is consistent with the change trend observed for hydrogen purity.

3.5.5 BET. Table 3 summarizes the specific areas, total pore volumes, and average pore diameters of the fresh and 10 cycle OCs. The fresh iron ore exhibited a small specific area $\left(0.303 \mathrm{~m}^{2} \mathrm{~g}^{-1}\right)$ and total pore volume $\left(0.0015 \mathrm{~cm}^{3} \mathrm{~g}^{-1}\right)$, indicating that it was not a porous material, which was not favorable to the gas diffusion in the chemical looping process. The specific areas of the OCs increased after loading with metal oxides. This was attributed to the metal oxides deposited on the surface of the iron ore. The fresh CuO-iron ore exhibited the highest specific area, $0.746 \mathrm{~m}^{2} \mathrm{~g}^{-1}$, among the three modified OCs, but it decreased significantly to $0.422 \mathrm{~m}^{2} \mathrm{~g}^{-1}$ after 10 cycles. The specific area decreased slightly from $0.603 \mathrm{~m}^{2} \mathrm{~g}^{-1}$ and $0.549 \mathrm{~m}^{2} \mathrm{~g}^{-1}$ to $0.582 \mathrm{~m}^{2} \mathrm{~g}^{-1}$ and $0.513 \mathrm{~m}^{2} \mathrm{~g}^{-1}$ for the NiOiron ore and $\mathrm{CeO}_{2}$-iron ore during the cycle tests, respectively. Combined with the results of the cycle tests, we can conclude that the NiO-iron ore and $\mathrm{CeO}_{2}$-iron ore both had higher sintering resistance and thermal stability than the CuO-iron ore.

\section{Conclusions}

The CLH production process with the modified iron ore as OCs was conducted in a fluidized-bed reactor, where the OCs were first reduced by simulated BPG and then reacted with steam to produce $\mathrm{H}_{2}$, and finally fully oxidized by air. The carbon capture efficiency increased with the decrease in the reduction time, but it presented an opposite trend as the temperature increased in the FR. Increasing the reduction temperature and time can improve the hydrogen yield. It was concluded that a condition of $900{ }^{\circ} \mathrm{C}$ with the reduction time of $40 \mathrm{~min}$ was suitable for hydrogen production and carbon capture. At this condition, the carbon capture efficiency for the NiO-iron ore, $\mathrm{CuO}$-iron ore and $\mathrm{CeO}$-iron ore were $83.29 \%, 82.75 \%$ and $70.05 \%$, respectively. The corresponding hydrogen yield and purity were $8.89 \mathrm{mmol} \mathrm{g}^{-1}$ and $99.02 \%, 7.78 \mathrm{mmol} \mathrm{g}^{-1}$ and $99.68 \%$, and $6.25 \mathrm{mmol} \mathrm{g}^{-1}$ and $99.52 \%$, respectively. $\mathrm{NiFe}_{2} \mathrm{O}_{4}, \mathrm{CuFe}_{2} \mathrm{O}_{4}$ and $\mathrm{CeFeO}_{3}$, which were observed in the $\mathrm{CuO}$-iron ore and $\mathrm{NiO}$-iron ore samples, enhanced the reactivity of the iron ore and promoted its reduction. Both NiO-iron ore and $\mathrm{CeO}_{2}$-iron ore exhibited good cycle performances, while the sintering of the $\mathrm{CuO}$-iron ore led to a decrease in the reactivity. Although the NiO-iron ore exhibited the highest carbon deposition and the lowest hydrogen purity compared with the CuO-iron ore and $\mathrm{CeO}$-iron ore, the NiO-iron ore was the best OC for hydrogen production due to its high hydrogen yield and high cycle performance.

\section{Conflicts of interest}

There are no conflicts to declare.

\section{Acknowledgements}

The research received financial support from the National Key Research and Development Program of China (2018YFB1502901). Meanwhile, the authors would also like to acknowledge the Analytical and Testing Center of Huazhong University of Science \& Technology (HUST) for the analysis of the OC samples.

\section{References}

1 I. Dincer and C. Acar, Int. J. Hydrogen Energy, 2017, 42, 14843-14864.

2 R. Kothari, D. Buddhi and R. L. Sawhney, Renewable Sustainable Energy Rev., 2008, 12, 553-563.

3 M. Luo, Y. Yi, S. Wang, Z. Wang, M. Du, J. Pan and Q. Wang, Renewable Sustainable Energy Rev., 2018, 81, 3186-3214.

4 S. Ma, S. Chen, A. Soomro and W. Xiang, Int. J. Hydrogen Energy, 2017, 42, 11006-11016.

5 T. Mendiara, F. García-Labiano, A. Abad, P. Gayán, L. F. de Diego, M. T. Izquierdo and J. Adánez, Appl. Energy, 2018, 232, 657-684.

6 D. Zeng, S. Peng, C. Chen, J. Zeng, S. Zhang, H. Zhang and R. Xiao, Int. J. Hydrogen Energy, 2016, 41, 22711-22721.

7 D. Zeng, R. Xiao, S. Zhang and H. Zhang, Fuel Process. Technol., 2015, 139, 1-7.

8 K. Kang, C. Kim, K. Bae, W. Cho, S. Kim and C. Park, Int. J. Hydrogen Energy, 2010, 35, 12246-12254.

9 K. Svoboda, A. Siewiorek, D. Baxter, J. Rogut and M. Punčochář, Chem. Pap., 2007, 61, 110-120.

10 S. Takenaka, N. Hanaizumi, V. T. D. Son and K. Otsuka, J. Catal., 2004, 228, 405-416.

11 P. Chiu and Y. Ku, Aerosol Air Qual. Res., 2012, 12, 1421-1432.

12 P. Chiesa, G. Lozza, A. Malandrino, M. Romano and V. Piccolo, Int. J. Hydrogen Energy, 2008, 33, 2233-2245. 
13 D. Zeng, Y. Qiu, S. Peng, C. Chen, J. Zeng, S. Zhang and R. Xiao, J. Mater. Chem. A, 2018, 6, 11306-11316.

14 Z. Huang, F. He, Y. Feng, K. Zhao, A. Zheng, S. Chang, G. Wei, Z. Zhao and H. Li, Energy Fuels, 2013, 28, 183-191.

15 Q. Chen, S. Hu, J. Xiang, S. Su, L. Sun, Y. Wang, L. Zhang and H. Chi, Fuel Process. Technol., 2016, 146, 56-61.

16 M. Ismail, W. Liu and S. A. Scott, Energy Procedia, 2014, 63, 87-97.

17 R. V. Siriwardane, E. Ksepko, H. Tian, J. Poston, T. Simonyi and M. Sciazko, Appl. Energy, 2013, 107, 111-123.

18 S. Sun, M. Zhao, L. Cai, S. Zhang, D. Zeng and R. Xiao, Energy Fuels, 2015, 29, 7612-7621.

19 Z. Yu, Y. Yang, S. Yang, Q. Zhang, J. Zhao, Y. Fang, X. Hao and G. Guan, Carbon Resour., 2019, 2, 23-34.

20 H. Leion, E. Jerndal, B. Steenari, S. Hermansson, M. Israelsson, E. Jansson, M. Johnsson, R. Thunberg, A. Vadenbo, T. Mattisson and A. Lyngfelt, Fuel, 2009, 88, 1945-1954.

21 T. Song, T. Shen, L. Shen, J. Xiao, H. Gu and S. Zhang, Fuel, 2013, 104, 244-252.

22 H. Leion, A. Lyngfelt and T. Mattisson, Chem. Eng. Res. Des., 2009, 87, 1543-1550.

23 D. Zeng, R. Xiao, Z. Huang, J. Zeng and H. Zhang, Int. J. Hydrogen Energy, 2016, 41, 6676-6684.

24 R. Xiao, S. Zhang, S. Peng, D. Shen and K. Liu, Int. J. Hydrogen Energy, 2014, 39, 19955-19969.

25 Z. Huang, F. He, Y. Feng, R. Liu and K. Zhao, Int. J. Hydrogen Energy, 2013, 38, 14568-14575.

26 Z. Yu, C. Li, Y. Fang, J. Huang and Z. Wang, Energy Fuels, 2012, 26, 2505-2511.

27 Z. Huang, F. He, K. Zhao, A. Zheng, H. Li and Z. Zhao, Prog. Chem., 2012, 24, 1599-1609.

28 J. Lachén, J. Plou, P. Durán, J. Herguido and J. A. Peña, Int. J. Hydrogen Energy, 2017, 42, 13607-13616.

29 L. Wang, L. Shen, W. Liu and S. Jiang, Energy Fuels, 2017, 31, 8423-8433.
30 W. Liu, L. Shen, H. Gu and L. Wu, Energy Fuels, 2015, 30, 1756-1763.

31 H. Gu, S. Lang, G. Song, S. Zhang, M. Niu, W. Liu and L. Shen, Chem. Eng. J., 2019, 360, 260-270.

32 J. Bao, Z. Li and N. Cai, Ind. Eng. Chem. Res., 2013, 52, 61196128.

33 H. Gu, L. Shen, J. Xiao, S. Zhang, T. Song and D. Chen, Combust. Flame, 2012, 159, 2480-2490.

34 M. M. Hossain and H. I. de Lasa, Chem. Eng. Sci., 2008, 63, 4433-4451.

35 T. Mendiara, A. Abad, L. F. de Diego, F. García-Labiano, P. Gayán and J. Adánez, Chem. Eng. J., 2019, 359, 37-46.

36 M. A. Pans, P. Gayán, L. F. de Diego, F. García-Labiano, A. Abad and J. Adánez, Chem. Eng. Res. Des., 2015, 93, 736746.

37 X. Wang, Z. Chen, M. Hu, Y. Tian, X. Jin, S. Ma, T. Xu, Z. Hu, S. Liu, D. Guo and B. Xiao, Chem. Eng. J., 2017, 312, 252-262.

38 H. Shin, S. Choi, K. Jung and S. Han, Chem. Mater., 2001, 13, 1238-1242.

39 D. Zeng, R. Xiao, S. Zhang and H. Zhang, Fuel Process. Technol., 2015, 139, 1-7.

40 Z. Gu, K. Li, S. Qing, X. Zhu, Y. Wei, Y. Li and H. Wang, RSC Adv., 2014, 4, 47191-47199.

41 B. Wang, R. Yan, H. Zhao, Y. Zheng, Z. Liu and C. Zheng, Energy Fuels, 2011, 25, 3344-3354.

42 X. Niu, L. Shen, S. Jiang, H. Gu and J. Xiao, Chem. Eng. J., 2016, 294, 185-192.

43 S. Jiang, L. Shen, J. Wu, J. Yan and T. Song, Chem. Eng. J., 2017, 317, 132-142.

44 A. M. Banerjee, M. R. Pai, S. S. Meena, A. K. Tripathi and S. R. Bharadwaj, Int. J. Hydrogen Energy, 2011, 36, 4768-4780.

$45 \mathrm{~K}$. Li, M. Haneda, Z. Gu, H. Wang and M. Ozawa, RSC Adv., 2013, 93, 129-132.

46 K. Li, H. Wang, Y. Wei and D. Yan, Chem. Eng. J., 2010, 156, 512-518.

47 X. Zhu, K. Li, Y. Wei, H. Wang and L. Sun, Energy Fuels, 2014, 28, 754-760. 